\title{
Eroticism, Mysticism, and Desire in Julio Cortázar's Rayuela
}

\author{
Mary Lousa Cappelli, MFA, JD, PhD \\ Nevada State College
}

\begin{abstract}
Beneath the lyrical fabric of Julio Cortázar's works lies a strong mystical quest to uncover the erotic truth amidst the cacophony of socio-religious constrictions. Informed by George Bataille, I explore how Julio Cortázar's Rayuela synthesizes lyrical images of the nude and orgasmic to unshackle human sexuality from religious traditions thereby liberating human desire to an orgasmic symphony of divine communion.
\end{abstract}

Keywords - Georges Bataille; Julio Cortázar; Rayuela; Hopscotch; taboo; trans gression; love; eroticis m; sexuality; sacred; metaphysics; profane; desire.

\section{INTRODUCTION}

A 1937 legend establishes that in the secret society Acephale, Georges Bataille desired the community to be consecrated through the performance of ritual sacrifice. Historical findings substantiate that he was indeed sincere in this desire with one of its members offering his life as the sacrifice (Richardson, 1999, p. 375). Bataille believed that sacrifice testifies to the inner needs that are being suppressed and that "sacrifice is the closest we come to an experience of erotic ism" (Richardson, 1999, p. 375). These moments of extre me behavior, of the primitive, raw sense of life are expressed through Julio Cortázar's Oliveira in Rayuela (Hopscotch) in which his ordeals provide a liminal space to break through the limits of consciousness. Informed by Bataille's dialect of taboo and transgression, I explore the ways in which Oliveira's extreme and transgressive sexual behaviors lead to the mystical sacred.

Cortázar employs the sacred as a "form of negativity without cause and eroticism as a pattern of transgressive excess" to show how Oliveira's journey "de los lados de alla"l moves from crisis to liberation (Rival, Slater, \& Miller, 1999, p. 297). Within this space, disruptions occur in order to hasten the dis solution of the boundaries of self. In Rayeuela, I argue that erotic ism or the sacrificial death of the self is a necessary condition of Oliveira's transcendence.

\section{TABOO AND TRANSGRESSION}

Cortázar (1998) depicts "una confusa lista de ejercitios a contrapelo que habia que hacer, aprobar, ir dejando atras"(p. 243). ${ }^{2}$ This confused list of exercises suggests Cortázar's intended refusal of any concentric order that a reader might wish to impose on the text (Safir, 1976, p. 558). He moves the reader randomly and more often than not between different situations, different geographies, different friends, and different moments in life leaving the reader vulnerable to the inexplicable uncertainty of life's trajectory. Oliveira's sexual encounters suggest a masochist dimension of a subculture attempting to reinvent itself, and to transform itself through the exercise of power. Specifically, Chapter 36 of the novel chronicles a violent labyrinth of darkness and excess initiating our hero toward a difficult path of taboos, transgressions, and sexual exploration. Cortázar depicts the grotesque nature of the underworld, el otro lado. ${ }^{3}$ In one pivotal scene, Emmanuéle's grubby appearance repels Oliveira and heightens the dialectical nature of taboo and transgression.

Untrain the senses, open your mouth and nose wide and take in the worse of smells, human funkiness. One minute, two, three, easier and easier, like apprenticeship. Keeping his nausea under control, Oliveira grabbed the bottle, even though he couldn't see he knew the neck was anointed with spit and lipstick, the darkness sharpened his sense of smell. Closing his eyes to protect himself against something, he wasn't sure what it was, he downed half a pint of wine in one gulp. Then they started to smoke, shoulder to shoulder, satisfied. The nausea went away, not conquered but humiliated, waiting there with its crooked head, and begin to think about anything. (Cortázar 1996, p. 209)

On his arrival, Oliviera is sickened by the world of "spit," "lipstick" and excess - a clear separation from a social order of niceties and propriety. He has entered the darkened spaces where violation and extreme erotic behavior lurk beneath the surfaces to subvert social taboos. His nausea is 
fundamental to the scene because it suggests his awareness of the world of taboo and transgression, which he encounters. His revulsion is a precondition to "something which must exist in order to be consciously overcome, thus achieving movement toward planes beyond habitual limits" (Safir, 1976, p. 560). He is awakened to the my riad faces of human existence - the ordinary, the mystical, the sacred, the transgressive, the primitive, the raw the erotic, the destructive, and the scatological. Therefore, he must enter the cave and experience all of these contradictory states of being in order to return and be fully restored. For Bataille, "Encounters with horror, violent disgust, that miraculously transform into experiences of laughter, into xication, ecstasy," overpower the dualistic binary of "interiority or exteriority" (Botting \& Wilson, 1997, p. 2). Oliveira observes the necessity of seeing past the binary and to envision "del otro de allá"- the world from the wrong end of the kaleidoscope. He remarks:

$\{F\}$ rom there begin to look out from the from the mountain of manure, look at the world through the eye of your as shole and you'll see patterns pretty as can be, the pebble had to pass through the eye of your asshole, kicked along by the tip of your toe, and from Earth to Heaven the squares would be open, the labyrinth would unfold like the spring of a broken clock as it made workmen's time fly off in a thous and pieces, and through the snot and semen and stink of Emmanuéle and the shit of the Obscure one you would come onto the road leading to the kibbutz of desir\{e\}... (Cortázar 1996, p. 215-216)

The imagery of discharge and excess fluids of "manure," "snot and semen," illustrates Bataille's "principle of expenditure" in which bodily fluids must be released (Botting \& Wilson, 1997, p. 26). Human bodily functions are dependent on the release of unused energy. As Bataille (1967) writes: "Excess must be spent" as it is a precondition for growth and sustenance (p. 183-4). In this sense, eroticis $\mathrm{m}$ is a bodily ritual of "expenditure" in which, "erotic activity always takes place at the expense of the forces committed to their combat (Bataille, 1967, p. 273).

In the scene in which La Maga becomes savage during sex, she bites Oliveira and draws blood. He, in return, matches her, dominating her in bed. Eventually, Maga develops a fantasy of Oliveira killing her in the throes of sex, only to resurrect her as his intellectual equal. Through the violent play of orgasmic convulsions, they experience the liminality of the sacred. At once immanent and transcendental, their erotic sexuality lies beyond the monstrous condition of social stagnation and finitude that plagues humanity. Their transgressive sexual relations affirms Bataille's declaration that "the purpose of debauch is to alone oneself in order to become Godlike" (Rival, Sater, \& Miller, p. 298). In Bataille's brand of materialism, the body, particularly the sexual organs when used for nonreproductive purposes and wasteful activities are sacred. It is deemed sacred because the body is corruptible and mortal. Orgasm as an ecstatic initiatory experience gains in mysticis $m$ if it is attained in the raw fornicated and tortured loss of individualism to the consummated act itself (Bataille, 1967). Within th is relationship we see Cortázar's quest for a new moral order free from compulsion and external imposition. Similar to Bataille, Cortázar's sexuality is experienced as a religious sacrifice, through guilt, shame, and transgression. Religious in nature, it is based on the heteronomic internalization of the sacred, which he locates beyond mortality, rationality and sociality. "Erotic is $\mathrm{m}$, then, for both male and female subjects, but in different ways, connotes a tearing, an opening on to something entirely other, the abjection of being before an experience which appears sovereign" (Botting, Wilson \& Scott, 1997, p. 13).

Viewing this sadomasochistic scene on a performative axis, we see both Oliveira and Maga struggling to take control of time and rhythm by entering and leaving a space open for the erosion of the illusion of separation and boundaries. Cortázar places erotic sexuality outside and in opposition to society as a virtual loss of consciousness and ecstatic surrender. Oliveira and La Maga's physical-psychic relationship and sexual release embody the allegorical struggle between Oliveira's enlightenment ideals and La Maga's Romantic aesthete, living life experientially, as a work of art. It is only when Oliveira is with Pola does he close off his mental preoccupations to experience sexual abandonment and real, unexamined sexual pleasure (Cortázar, 1996, p. 366). When Oliveira fondles and kisses Pola's cancerous breast his thoughts shut down to experience the moment. "He managed to stop thinking, just for an instant, he managed to kiss without it being anything but his own kiss" (Cortázar, 1996, p. 367). This scene invokes the stripping away of Horatio's conscious self and an absorption into the moment. Sexuality, here, becomes complicit with death as time stands still in the moment of orgasmic rapture.

\section{HOPSCOTCH}

Oliveira's descent into the darkness of his soul further explores the illusive nature of redemptive consciousness when Oliviera is confronted with his aloneness in the 
symbolic numerical chapter of 36 in which he is enveloped in a "night of empusae and lamiae, evil shadows, at the end of the game" (Cortázar, 1996, p. 241). Here, after leaving La Maga alone with her dead child, Rocamadour, he drifts to the Seine beneath the bridge of the Pont des Arts, wondering if he will ever find transcendent meaning. Oliveira must wander life's labyrinth, as the Serpent Club has met for its final meeting, and the mournful La Maga disappeared after the death of her son. He will spend the next part of his journey searching for La Maga and conjuring her in his dreams, as "La Maga would cease being a lost object and become the image of a possible reunionno longer with her but on this side of her or on the other side of her; by her, but not her" (Cortázar 1996, p. 111).

Oliveira's ritual initiates him into the "long path marked with pitfalls, obscurities, stops which suddenly comes to surface" (Safir, 1976, p. 559). In his brief sexual encounter with Emmanuéle, after she begins to perform oral sex on Oliveira, they are interrupted by the police and carted off in a patrol wagon. On the patrol car floor he contemplates whether he will ever be able to hopscotch in Heaven. These despairing reflective moments contain the most comprehensive examination of hopscotch as a metaphorical conceit for Oliveira's journey, which is developed throughout the novel. First encountered when describing Oliveira's love for La Maga as "that crazy hopscotch," it is later developed as a metaphor for transcending from earth to heaven (Cortázar, 1996, p. 95). Indeed, there are myriad variations on the children's game in which players toss a small object into a pattern of numbered boxes or circles drawn in chalk on the ground and then hop through the spaces to retrieve the object. Cortázar describes the game as "spiral hops cotch, rectangular hops cotch, fantasy hopscotch, not played very often" (p. 214). There are several recurring images of hopscotch where the reader is called to hop, skip and jump around the text hoping like Oliveira to find "the last square, the centre of the mandala" (Cortázar, 1996, p. 321).

Oliveira muses on the children that hop to "heaven" with a stone and chalk, acutely cognizant that he has, in his intellectual learning and pursuit of rational knowledge, forfeited his way to paradise - his kibbutz, as he calls it. Later, Oliveira muses:

Childhood is over all of a sudden and you're into novels, into the anguish of the senseless divine trajectory, into the speculation about another Heaven that you have to learn to reach too. And since you have come out of childhood ... you forget that in order to get to Heaven you have to have a pebble and a toe. (Cortázar, 1996, p. 214)

The Club and Morelli interrogate the legitimacy of this preAdamite ideal, a utopia that existed before hu manity gained knowledge and experience. Now, the Club and Oliveira have been cast out of its imaginary Edenic community, their rational critical minds incapable of thinking its way out of the humanity of their lives, and the real human tragedy they have experienced - the persistent yearning for Morelli, a "millenary kingdom" unrealized.

Cortázar further exposes the juxtaposition of these modern binaries, one rational and ordinary and the other experientially destructive and sacred, emphasizing that it within this abject horror of loss, expenditure and death that the initiation to the sacred begins. Oliviera transforms to "El Nuevo" the symbolic newcomer to the world of shadows and the negation of rational illumination. The surrealist nocturnal descent is cast as a time of danger for the subversion of the taboos that govern the day. As such, Oliveira's descent represents an agreement between means and metaphysics in which it is necessary to pass to another plane in order to then return restored and reborn. His descent recalls other Western Metaphysical descents into to the "other world" like those of Odysseus, Dante, and Christ who all (afterward) emerge closer to the desired understanding of ultimate truths. Cortázar's Oliveira imitates these metaphysical steps in which he breaks from bourgeois society to join the socially marginalized or what Bataille refers to as the "underworld" a subculture which exist outside the exigencies of work, yet clearly toward "el otro lado."

Oliveira's initial reluctance to completely reject Bourgeois life is evidenced with his initial relationship with Emmanuéle whose filth and disorder represent the death and decay of human morality. His nausea at her decay signifies the consciousness of the taboo in which he characterizes as the "worst of s mells, human funkiness." He keeps his nausea under control grabbing a bottle and downing "half a pint of wine in one gulp." It is at this point, that "they started to smoke, shoulder to shoulder, satis fied." The nausea goes away, and they enter a shared word of hallucinatory visions of the absurd, in which taboos are challenged and violence and eroticism emerge unchecked. In Oliveira's vision he contemplates Emmanuéle and observes:

The spots of dirt on her forehead, her thick lips stained with wine, The triumphal scarf of the Syrian goddess that had been trampled on by some other enemy army, a chryselephantine head rolling 
around in the dust, with spots of blood and gore

but keeping all the while the diadem of red and green stripes, the Great Mother stretched out in the dust and trampled on by drunken soldiers who amused themselves by pissing on her mutilated breasts, until the greatest clown a mount them knelt down to the accolade of all the others, his penis standing our erect above the fallen goddess, masturbating onto the marble and the letting the sperm trickle into the eye-holes from which officers' hands had already plucked the precious stones to the half-open mouth which accepted the humiliation as a final offering before rolling off into oblivion. (Cortázar 1996, p. 209)

Here, eroticis $m$ and death shape and order the transgressive vision, the signified taking on a semiotic meaning. Images of desecration and mutilation of the maternal reproductive organs proceed from the taboo as a consequence of a need to repress concepts of production and creation. The defilement of the female breasts as a symbolic life force is tied in with the violence and the violation. For Batialle (1988) posits that:

Only in violation, through death if need be, of the individual's solitariness can there appear that image of the beloved object which in the lover's eyes invests all being with significance. For the lover, the beloved makes the world transparent. (p. 21).

This juxtaposition of violence and reproduction is an aggression perpetrated on us by the fact of our birth and creation. Cortázar recognizes that both are inherent in our nature: creation itself is a fundamentally violent act and it is only through further violence of death that the breach it institutes can be repaired. Oliveira's vision represents the sacrificial moment of the Great Mother and the psychic reality of sacrifice within him. Blood, death, and sacrifice contain several interpretations from the primal act of childbirth and death to Christian concepts of resurrection and Eucharistic affirmations of "This is my body; this is my blood" in the body and blood of Christ. This depiction is one of violent anguish, which Oliveira experiences emerging as a dialectic at the heart of the impulse to sacrifice, and gains it most heightened communication in eroticism. Bataille (1988) puts it thus:

It is only in the midst of anguish that this being which you are maintains enough consistency and yet leaves gaping the wound through which, hastening from all points of the universe, deadly destruction enters. Without your anguish, you would not be this faithful mirror of excess movements, of the vertiginous flight of the day and night, which you have become. This is why it would not be for you to refuse that wild amplification of this pain, which you are suffering from, of the splendor, which follows you, and of your ultimate reality, which sacrifice is. (p. 195)

Oliveira's transgressive vision suggests how Cortázar affirms Bataille's (1988) assertion that "eroticism and sacrifice are both facets of ultimate reality, bringing us into contact with each other in the most raw, and human way" (p. 195). We witness similar desecration of the symbolic innocent in Enrique González Martinez's poem, "Tuercele el cuello al cisne," which relates closely to Oliveira's previous vision.

Tuck the neck to the swan of deceptive plumage that gives its white note to the blue of the fountain; he walks his grace no more, but he does not feel the soul of things or the voice of the landscape.

Flee from all forms and all language

that does not match the latent rhythm

of deep life and intensely loves

life, and may life understand your homage.

Look at the wise owl how he stretches his wings from Olympus, leaves Pallas's lap and poses in that tree the taciturn flight.

He does not have the grace of the swan, but his restless pupil who sticks in the shade, interprets the mysterious book of nocturnal silence. (Cortázar 1996, 213-217)

In Martinez's poem, the object of violence is the sacred swan being born from its mythological role in the rape of Leda and from the phallic value assigned to its powerful neck in modern Freudian terminology. The sacred swan's neck is strangulated "con un movimiento que simboliza la masturbacion," (with a movement that symbolizes masturbation) connecting both poem and vision together as similarly the soldier masturbates over the body of the fallen goddess. I conjecture that the poem and the vision represent an attempt at redemptive destruction, a concept articulated throughout Rayuela in which in order for life to be affirmed and resurrected something must die and/or be killed. Throughout the novel, Cortázar weaves aggressive erotica of executions, rape and the torturous death of an animal, heightening the metaphysical urgency of a climatic release 
from Oliveira's existential crisis. It is within the destructive, drunken, perverse nature of Oliveira's being that he affirms that one must descend and break the structures that strangle human dignity in order for humanity and society to be restored.

\section{CONCLUSIONARY THOUGHTS}

My interest in the writings of George Bataille and Julio Cortázar began when I was teaching a class in Love and Eroticism at Emerson College in Boston. I was fascinated by how writers mix the sacred and the profane and how we cannot truly speak of love and eroticis $m$ without also including sexuality and death in the discussion. I was further fascinated by Georges Bataille's theories and Julio Cortázar's fictional discourses on eroticism. I was not so much interested about the exploration of human sexuality and eroticis $m$, but about death, "une petit morte" of descent, resurrection, rupture and the glorification of life's liminal spaces. Bataille believed that because we have somewhere lost our ability to sacrifice, we have also lost our sense of death and human connection. For with the imminence of death comes complete awareness of our insignificance in a vast universe. With the imminence of death, comes awareness of our primal loss. "In one way or another everyone is looking for it, everyone wants to open the door that leads out to the playground. And not just Eden ... the retirement from kicks in the ass" (Cortázar, 1996, p. 387). In the end, we, as readers, like Horacio Oliveira, would like a respite from the punches and kicks that life throws at us. Ultimately, we must all confront our deepest fears-our vulnerability, our morality, our ultimate aloneness in a vast universe-those liminal spaces that daily sustain and challenge us to hopscotch and keep on keeping on.

\footnotetext{
${ }^{1}$ Translates to from the sides of there.

2 Translates to a confusing list of exercises against the grain that had to be done, approved, left behind.

3 Trans lates to the other side.
}

\section{REFERENCES}

Bataille, G. (1967). The BAccursed Share. Vol. I Consumption. Translated by Robert Hurley. New York: Zone Books. Reprint. 1988.

Bataille, G. Inner Experience. (1943). Translated by Leslie Anne Boldt Albany: State University of New York Press. Reprint 1988.

Bataille, G. (1967). The Accursed Share. Vols. 2 and 3 The History of Eroticism and Sovereignty. New York. Zone Books. Reprint. 1999.

Barthes, R. S/Z, Richard Miller, Tr. New York: Hill \& Wang.

Botting, F. \& Wilson, S. (1997). The Bataille Reader. Oxford: Blackwell Publisher.

Cortázar, J. (1968). Rayuela $9^{\text {th }}$ Edition. Buenos Aires: Sudamericana. p. 430.

Cortázar, J. (1996). Hopscotch. New York: Pantheon.

Rival, L., Slater, D., \& Miller, D. (1999). "Sex and Sociability: Comparative Ethnographies of Sexual Objectification.” In Ed. Mike Featherstone's Love and Eroticism. London: Sage Publications (295-322).

Richardson, M. (1999). "Seduction of the Impossible: Love, the Erotic and Sacrifice in Surrealist Discourse. In Ed. Mike Featherstone's Love and Eroticism. London: Sage Publications.

Safir, M. A. (1976). "An Erotics of Liberation: Notes on Transgressive Behavior in Rayuela and Libro de Manuel." Books Abroad. Vol. 50, No. 3. 558-570 